\title{
Identification of Broad Spectrum Blast Resistance Genes for North-East and Eastern India using Standard International Blast Differential
}

\author{
Shamshad Alam ${ }^{1,2} *$, Jahangir Imam, Dipankar Maiti ${ }^{1}$, N.P. Mandal ${ }^{1}$, \\ Chandeshwar Prasad ${ }^{2}$ and Mukund Variar ${ }^{1}$
}

${ }^{1}$ Biotechnology Laboratory, Central Rainfed Upland Rice Research Station (CRRI), Post Box 48, Hazaribag, Jharkhand, India

${ }^{2}$ Department of Botany, Vinoba Bhave University, Hazaribag, Jharkhand, India

\author{
*Corresponding author
}

\begin{tabular}{|l|}
\hline Key w or d s \\
Differentials, \\
Magnaporthe \\
oryzae, Resistant \\
gene, Rice, \\
Virulence analysis \\
\hline Article Info \\
\hline $\begin{array}{l}\text { Accepted: } \\
\text { 20 March } 2019 \\
\text { Available Online: } \\
\text { 10 April } 2019\end{array}$ \\
\hline
\end{tabular}

\section{Introduction}

Blast disease of rice caused by filamentous
fungus Magnaporthe oryzae (Couch and
Kohn, 2002), is a devastating disease

Blast disease of rice caused by filamentous
fungus Magnaporthe oryzae (Couch and
Kohn, 2002), is a devastating disease

Blast disease of rice caused by filamentous
fungus Magnaporthe oryzae (Couch and
Kohn, 2002), is a devastating disease

\section{A B S T R A C T}

Rice Blast caused by the fungal pathogen Magnaporthe oryzae is one of the most devastating diseases worldwide. Host plant resistance is the effective and economical way to manage this disease. Host plant resistance has been exploited as source for developing resistant variety since past. Challenge (host resistance) induced shifts in pathogen variabilities necessitates continuous development of need based resistant varieties. Knowledge on ever-changing and location specific variability pattern of pathogen, with reference to known, available blast resistant genes, is prerequisite for such efforts. Attempt was made in the present study to analyze virulence spectrum of $90 \mathrm{M}$. oryzae isolates collected from different geographical regions of North-East and Eastern India using monogenic differentials targeting 26 major blast resistant genes $P i 9$, Piz5(Pi-2), Pita' ${ }^{2}$ Pita ${ }^{2}$, Piz, Pi1, Pi5, Pi7, Pii, Pi20(t), Pil1, Pi-kh, Pi-km, Pi-ks, Pi12(t), Piz-t, Pi-sh, Pik, Pib, Pi3, Pit, Pil9(t), Pita, Pi-kp, Pita (Pi-4) and Pi-a under green house conditions. Resistance percentage ranged from $19.7 \%$ to $94.2 \%$ among the monogenic lines. All the 90 isolates produced virulent reaction on susceptible check Lijiangxintuanheigu (LTH). Pi9, Piz5(Pi2), Pita ${ }^{2}, P i z$ and Pil genes showed wide resistance spectra respectively and can be important $\mathrm{R}$ gene for preventing blast disease. Matching virulence to all resistance genes were detected in the pathogen population. The genes Pi9 $(94.2 \%)$ and Pita ${ }^{2}(78.2 \%)$ showed complementary resistance spectrum and the monogenic lines carrying these genes together, showed resistant reaction to all 90 isolates. These results suggest that combination of $P i-9+$ $\mathrm{Pita}^{2} \mathrm{Pi}$ P $+\mathrm{Piz}, \mathrm{Pi} 9+\mathrm{Piz}, \mathrm{Pi}+\mathrm{Pil}, \mathrm{Piz}+\mathrm{Pil}$ and $\mathrm{Piz}+\mathrm{Pil}$ may play an important role in prevention of blast disease across all the locations. Based on above data, a useful strategy can be formulated for the management of rice blast disease by stacking R-genes against pathogenic M. oryzae isolates for this geographical region. affecting rice production every year globally (Ou, 1985). The pathogen infects rice crop at every growth stages starting from seedling to grain filling stage and cause substantial yield loss (Dean et al., 2005). India is second 
largest rice producing nation of the world. In India, rice blast is prevalent in all rice growing regions with highest incidence in Eastern India followed by North and South India (Variar et al., 2009; Khush and Jena, 2009). According to one estimate, in Eastern India about 564,000 tons of rice is lost due to blast of which nearly $50 \%$ (246,000 tons) is in the upland ecosystem (Widawsky et al., 1990). Blast fungus shows a high degree of variability in the field leading to frequent emergence of new races knocking down prevalent resistant cultivars (Valent et al., 1991). Any change in frequency of virulence directly challenges the effectiveness of resistant cultivars (Kiyosawa., 1982). Further, transposable elements (TE) have been implicated in the emergence of virulent forms of the pathogen by their frequent insertion into avirulence genes as reported in case of Avr-Pita, Avr-Piz-t and Acel gene (Zhou et al., 2007; Li et al., 2009 and Bohnert et al., 2004). Presence of TEs in $M$. oryzae population poses a continuous threat to the effectiveness of existing blast resistant cultivars. The average life span of many resistant rice cultivars is 2 to 3 years in blast prone environment (Leung et al., 1988). This necessitates continuous, location specific monitoring of pathogen variability based on virulence analysis against known major blast resistance genes for selection and deployment of effective genes or their combinations against prevalent pathotypes and maintain regular release of resistant cultivars in certain interval. Virulence analysis or pathotyping is a vital tool to determine the race variation, pathotype composition and effective blast resistance genes for any geographical location. This analysis is done with a genetically well-defined set of resistant sources (differentials) to obtain high degree of resolution for describing the virulence structure of a population. A new set of 26 differential varieties targeting 24 resistance genes in the genetic background of
Lijinanxintuanheigu (LTH) developed at International Rice Research Institute (IRRI) in collaboration with Japan International Rice Research Center for Agricultural Sciences (JIRCAS) (Tsunematsu et al., 2000; Kobayashi et al., 2007) was used to understand pathogenic variability in $M$. oryzae (Fukuta et al., 2010).

Blast disease can be controlled by various fungicides which are not environmentally safe and continuous use poses threat to emergence of resistant pathogen races (Kim et al., 2008). Use of resistant cultivar integrated with cultural practices is the most economical and effective way to control this disease (Roy Chowdhury et al., 2012; Bonman, 1992 and Lee, 1994). Several blast resistant varieties have been released but their resistance was knocked down few years after release because of emergence of novel pathogenic variation. Transposable elements have been implicated in the emergence of virulent forms of the pathogen by their frequent insertion into avirulence genes as reported in case of $A v r$ Pita, Avr-Pizt and Acel gene (Zhou et al., 2007; Li et al., 2009 and Bohnert et al., 2004). Presence of TEs in M. oryzae population poses a continuous threat to the effectiveness of existing blast resistant varieties. Therefore, virulence analysis is prerequisite to determine the diversity in the pathogen population and selection of effective blast resistant genes or their combination for the management of this disease.

In our previous study on molecular diversity and mating type distribution of $M$. oryzae isolates from North-East and Eastern India by Pot2-TIR and MGR586-TIR clearly indicated that high lineage diversity exist in this region. Eight and nine lineages from two different primers were identified in this region. Presence of both the mating type in the isolates of this region suggested the possibility of sexual recombination in nature 
which can affect the diversity and dissemination (Imam et al., 2015). Present study was taken up to determine the virulence diversity of $M$. oryzae isolates of this geographical region. Forty-three isolates representing each lineage and another fortyseven new isolates were selected for this study. The main objective of the present investigation is to (1) determine the virulence diversity of $M$. oryzae isolates (2) identify the effective resistance genes for this region and (3) develop breeding strategies for stacking multiple $R$ genes for durable blast resistance in North-East and Eastern India.

\section{Materials and Methods}

\section{Collection and maintenance of isolates}

The present study was conducted on $M$. oryzae isolates of Eastern and north eastern part of India collected from Assam, Jharkhand, Odisha, Meghalaya and Tripura over a period five years (2010-15) (Table 1). Two hundred- fifty blast infected leaf and neck blast samples were collected from different part of North-East and Eastern India during 2010 to 2015. Most of the collections were made from farmer's fields. Leaf blades with necrotic lesions were washed in tap water for 1 to $3 \mathrm{~min}$ and surface sterilized with $0.1 \%$ mercuric chloride. They were then washed serially with double distilled water and allowed for sporulation on sterilized glass slide by incubating in moist chamber at $28^{\circ} \mathrm{C}$ for $24 \mathrm{~h}$. Conidia were dislodged from individual sporulating lesions onto $2 \%$ agar plates with a sterilized glass needle. Single spores were picked up aseptically under a microscope and transferred to fresh Oat Meal agar slant. From each leaf or neck samples, mono-conidial isolates were prepared and maintained on desiccated filter paper following the procedure described by Hayashi et al., 2009. A total of ninety single spore isolates were selected on the basis of their sporulation ability for virulence analysis (Table 1).

\section{Monogenic differentials for virulence analysis}

Twenty-six international differentials (Tsunematsu et al., 2000; Kobayashi et al., 2007), each having single blast resistance gene introgressed into LTH genetic background was used in this study. The rice variety LTH was used as susceptible check and Tetep as resistant check. Five to seven seeds of each differential variety were planted in plastic trays $(54 \times 36 \times 7 \mathrm{~cm})$ filled with mixture of soil and FYM (3:1). All the trays were kept in green house at $25 \pm 1^{\circ} \mathrm{C}$ for 21 days until fourth leaf half emerged.

\section{Inoculation and disease evaluation}

Inoculation of blast isolates was done following the method of Hayashi et al., (2009) with slight modification. The stored cultures colonized on desiccated filter paper were grown on oat meal agar slants. Mycelia from 10-day-old slants were macerated in 5 $\mathrm{ml}$ of distilled water and plated onto OMA plates. The plates were incubated at $25 \pm 1^{\circ} \mathrm{C}$ for 6 days under fluorescent light for sporulation. After sporulation $10 \mathrm{ml}$ of sterilized distilled water was poured on to each culture plate. Using sterilized glass slide, the fungal growth surface was scraped and filtered through two layers of sterilized cheese-cloth. The spore concentration was adjusted to 1 x $10^{5}$ spore/ml. Tween-20 (@ $0.01 \%$ ) was added to the spore suspension as adhesive. The inoculum was sprayed onto 21 day- old seedlings using fine sprayer. The inoculated plants were then transferred to humidity chamber for 24 hours after which they were incubated in the greenhouse at $25 \pm 1^{\circ} \mathrm{C}$ for 6 days. Disease reaction of each differential line was evaluated 7 days after inoculation on $0-5$ scale according to the 
Standard evaluation system (SES, 1996) for rice blast developed at IRRI. The reactions of differential varieties were categorized into three classes viz.; 0-3= resistant (R), and 4$5=$ susceptible (S) (Zhou et al., 2003).

\section{Data analysis}

Resistance percentage and virulence frequency were calculated according to the following formulas:

Resistance percentage $(\%)=$ number of incompatible isolates / total number of rice lines or $\mathrm{R}$ genes tested $\times 100$

Virulence frequency $(\%)=$ number of virulent isolate on $\mathrm{R}$ genes/ total number of isolate tested $\times 100($ Saad et al., 2010)

\section{Results and Discussion}

\section{Useful blast R-genes}

Disease reaction of $90 \mathrm{M}$. oryzae isolate of North-East and Eastern India against twentysix international differentials revealed that Pi9, Piz5(Pi2), Pita ${ }^{2}, \mathrm{Pil}$ and Piz are potential resistance gene for resistance breeding program as they exhibited compatibility with less number of isolates. The percentage of resistance on international differentials targeting 26 major R-genes viz., Pi9, Piz5(Pi2), Pita ${ }^{2}$ Pita ${ }^{2}$ Piz, Pil, Pi5, Pi7, Pii, Pi20(t), Pill, Pi-kh, Pi-km, Pi-ks, Pi12(t), Piz-t, Pi-sh, Pik, Pib, Pi3, Pit, Pil9(t), Pita, Pi-kp, Pita (Pi-4) and $P i-a$ ranged from $19.7 \%$ to $94.2 \%$. The resistance check Tetep was found resistant to all isolates. Tetep is known to harbor at least four major blast resistance genes Pil, Pita, Pit and Pi54 (Inuikai et al., 1995) which contribute to its broad spectrum resistance. The percentages of resistant on monogenic lines carrying Pi9, Piz5(Pi2), Pita $^{2}$, Piz and Pil were 94.2\%, 92.5\%, 78.2\%, $71.5 \%$ and $67 \%$ which showed that these genes have wide resistance spectra to the prevalent isolates and can be useful to prevent blast disease in this region (Fig. 1 and Table 2).

\section{Virulence spectrum of M. oryzae isolates}

The study revealed that high virulence diversity exists in pathogen population of North-East and Eastern India (Table 3). All the Isolates were found virulent to one or more monogenic lines. The pathogen population comprises isolates virulent to minimum 3 to maximum 22 resistant genes out of 26. All isolates were virulent to LTH. Virulence frequency of different $M$. oryzae isolates was found to range from $10.7 \%$ (Moei-163) to $78.5 \%$ (Mo-ei-5a) (Fig. 2). Isolates originating from Jharkhand were more virulent than the isolates from other region of North-East and Eastern India as they exhibited compatibility with large number of resistant genes. Out of 90 isolates, Mo-5, Moei-76, Mo-ei-43 and Mo-ei-103 originating from Jharkhand had the highest virulence (Fig. 2).

\section{Gene combination strategy to develop durable resistance}

Matching virulence to all resistance genes were detected in the pathogen population. Most of the blast resistant genes expressed narrow resistant spectrum except few ( $P i 9$, Piz5(Pi2), Pita ${ }^{2}, P i z$ and Pi1) to the tested blast isolates of Eastern India, suggesting that most resistance genes were effective against a part of the pathogen population and it would be impossible to obtain desirable levels of resistance by the introgression of single resistant gene. Therefore, pyramiding of two or more resistant gene showing complementary resistant spectra will be needed to develop durable resistance. As shown in Table 3 and Figure 1, Pi9 gene expressed high level of resistance to most of 
the isolates (94.25\%) and can be exploited in combination with other effective resistant genes for achieving broad spectrum resistance. To excluding all the virulence of the pathogen population, various combinations of $P i 9$ and its allelic genes $P i z$, Piz5(Pi2) 1) Pi9 + Pita2; 2) Pi9 + Piz5; 3) $P i 9+P i z$; 4) Pi9 + Pil; 5) Piz5 + Pil; and 6) $P i z+P i 1$ were constructed. Out of all the combination, $P i 9+$ Pita $^{2}$ are expected to provide broad spectrum resistance across all the location by excluding all virulences of pathogen population.

North-East and Eastern region of India is considered as one of the hot pocket of rice genetic resource with extremely diverse rice growing conditions as compared to other parts of the country. Rice blast is endemic and major disease of this region because of high humidity during growth stage of rice. Until recently, pathogen variability was being studied as response to a set of differentials (Ling and Ou, 1969; Atkins et al., 1976, Yamada et al., 1976; Kiyosawa et al., 1984). However, the older differential varieties were inadequate to describe the genetic and phenotypic variability of $M$. oryzae populations because they were not uniform, contain more than one gene, also not present in single genetic background. The present study demonstrated that new monogenic differentials targeting 26 resistance genes (Tsunematsu et al., 2000; Kobayashi et al., 2007) in blast susceptible recurrent parent LTH are excellent material to identify the resistance spectra of resistant genes precisely against the blast isolates tested from Northeast and Eastern India. In our previous study on molecular diversity and mating type distribution of $63 \mathrm{M}$. oryzae isolates from North-East and Eastern India by Pot2-TIR and MGR586-TIR clearly indicated that high lineage diversity exist in this region. Eight and nine lineages from two different primers were identified in this region (Imam et al., 2015). Present study demonstrated virulence diversity of $M$. oryzae isolates of this geographical region. Based on our finding we proposed a strategy for stacking blast R-genes to achieve longer lasting resistance. Our results suggested that $P i-9, P i z 5(P i 2), P_{i t a}{ }^{2}$, Piz and Pil are most effective resistance genes and recommended to rice breeders for improving blast resistance in this region.

Table.1 Number of blast isolate phenotyped from different sites of Eastern and north eastern India

\begin{tabular}{|c|c|c|c|}
\hline SI.No. & State & District & No. of isolates Phenotyped \\
\hline \multirow[t]{3}{*}{1} & Assam & Gerua & 10 isolates \\
\hline & & Titabor & 4 isolates \\
\hline & & Jorhat & 1 isolate \\
\hline 2 & Tripura & Lembucherra & 6 isolates \\
\hline 3 & Meghalaya & Barapani & 1 isolate \\
\hline \multirow[t]{5}{*}{4} & Jharkhand & Ranchi & 8 isolates \\
\hline & & Hazaribag & 35 isolates \\
\hline & & Itkhori & 1 isolate \\
\hline & & Sankarpur & 3 isolates \\
\hline & & CRURRS, farm & 17 isolates \\
\hline \multirow[t]{2}{*}{5} & Orissa & Semiliguda & 4 isolates \\
\hline & & Total & 90 isolates \\
\hline
\end{tabular}


Table.2

\begin{tabular}{|l|l|l|c|c|}
\hline Sl.no. & Designation & R-Gene & No. of incompatible isolate & $\begin{array}{l}\text { Percentage of Incompatible } \\
\text { isolate (\%) }\end{array}$ \\
\hline $\mathbf{1}$ & IRBL1-CL & Pil & 59 & 67.04 \\
\hline $\mathbf{2}$ & IRBL11-ZH & Pill & 47 & 53.4 \\
\hline $\mathbf{3}$ & IRBL12-M & Pi12(t) & 47 & 24.22 \\
\hline $\mathbf{4}$ & IRBL19-A & Pi19(t) & 22 & 46.98 \\
\hline $\mathbf{5}$ & IRBL20-IR24 & Pi $20(t)$ & 39 & 33.7 \\
\hline $\mathbf{6}$ & IRBL3-CP4 & Pi3 & 30 & 62.92 \\
\hline $\mathbf{7}$ & IRBL5-M & Pi5 & 56 & 35.08 \\
\hline $\mathbf{8}$ & IRBL7-M & Pi7 & 20 & 94.25 \\
\hline $\mathbf{9}$ & IRBL9-W & Pi9 & 82 & 26.66 \\
\hline $\mathbf{1 0}$ & IRBLA-A & Pia & 24 & 37.07 \\
\hline $\mathbf{1 1}$ & IRBLB-B & Pib & 33 & 52.8 \\
\hline $\mathbf{1 2}$ & IRBLI-F5 & Pii & 47 & 37.07 \\
\hline $\mathbf{1 3}$ & IRBLK-KA & Pik & 33 & 46.66 \\
\hline $\mathbf{1 4}$ & IRBLKH-K3 & Pikh & 42 & 47.77 \\
\hline $\mathbf{1 5}$ & IRBLKM-TS & Pikm & 43 & 28.88 \\
\hline $\mathbf{1 6}$ & IRBLKP-K60 & Pikp & 26 & 51.11 \\
\hline $\mathbf{1 7}$ & IRBLKS-F5 & PikS & 46 & 44.44 \\
\hline $\mathbf{1 8}$ & IRBLSH-S & Pish & 40 & 32.95 \\
\hline $\mathbf{1 9}$ & IRBLT-K59 & Pit & 29 & 19.75 \\
\hline $\mathbf{2 0}$ & IRBLTA-CT2 & Pita (Pi4) & 16 & 30 \\
\hline $\mathbf{2 1}$ & IRBLTA-K1 & Pita & 27 & 78.16 \\
\hline $\mathbf{2 2}$ & IRBLTA2-PI & Pita2 & 68 & 78.2 \\
\hline $\mathbf{2 3}$ & IRBLTA2-RE & Pita2 & 61 & 71.59 \\
\hline $\mathbf{2 4}$ & IRBLZ-FU & Piz & 63 & 92.59 \\
\hline $\mathbf{2 5}$ & IRBLZ5-CA & Piz5 (Pi2) & 75 & 42.22 \\
\hline $\mathbf{2 6}$ & IRBLZT-T & Pizt & 38 & 0 \\
\hline $\mathbf{2 7}$ & Tetep & Tetep & 89 & 0 \\
\hline $\mathbf{2 8}$ & LTH & LTH & & \\
\hline & & & & \\
\hline
\end{tabular}

Fig.1 Resistance spectra of different R-genes

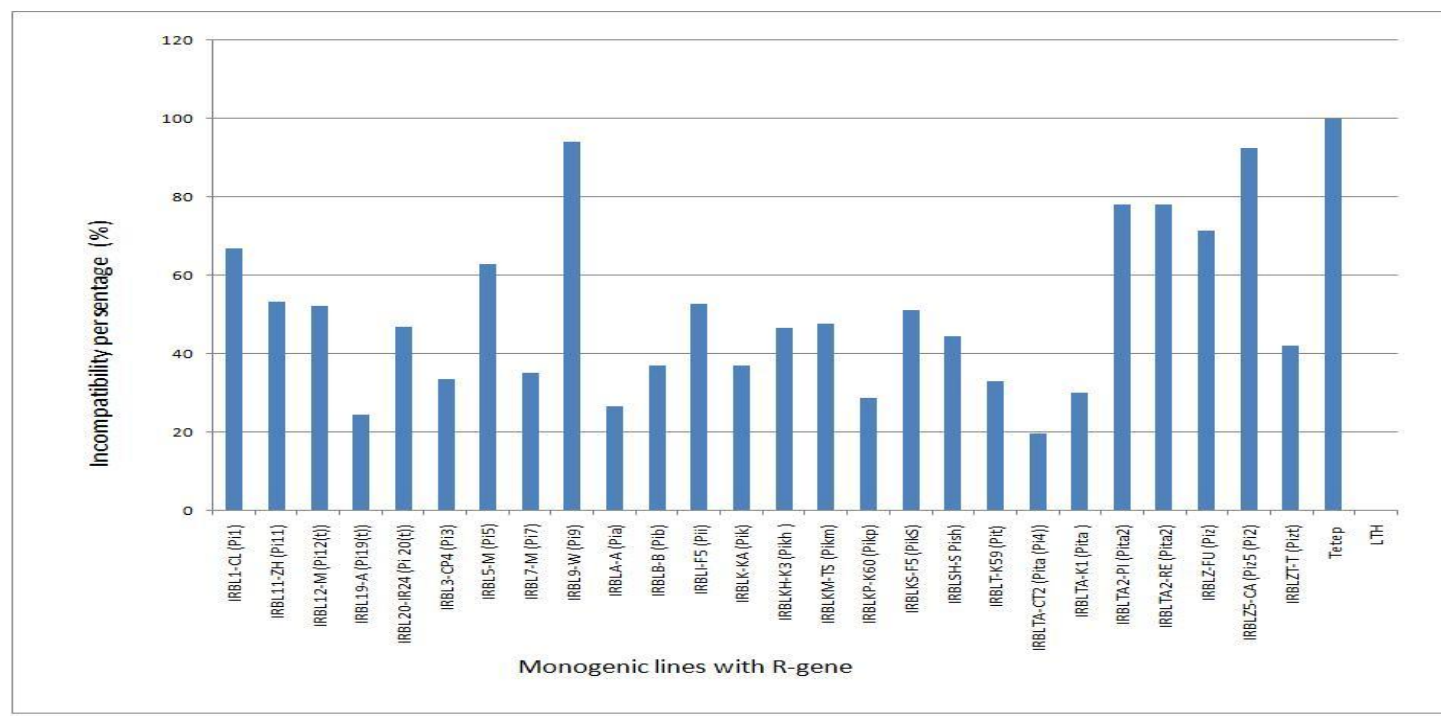


Fig.2 Virulence frequency of M. oryzae isolates (\%), AS: Assam, Jh: Jharkhand, MG: Meghalaya, OR: Odissa, TR: Tripura

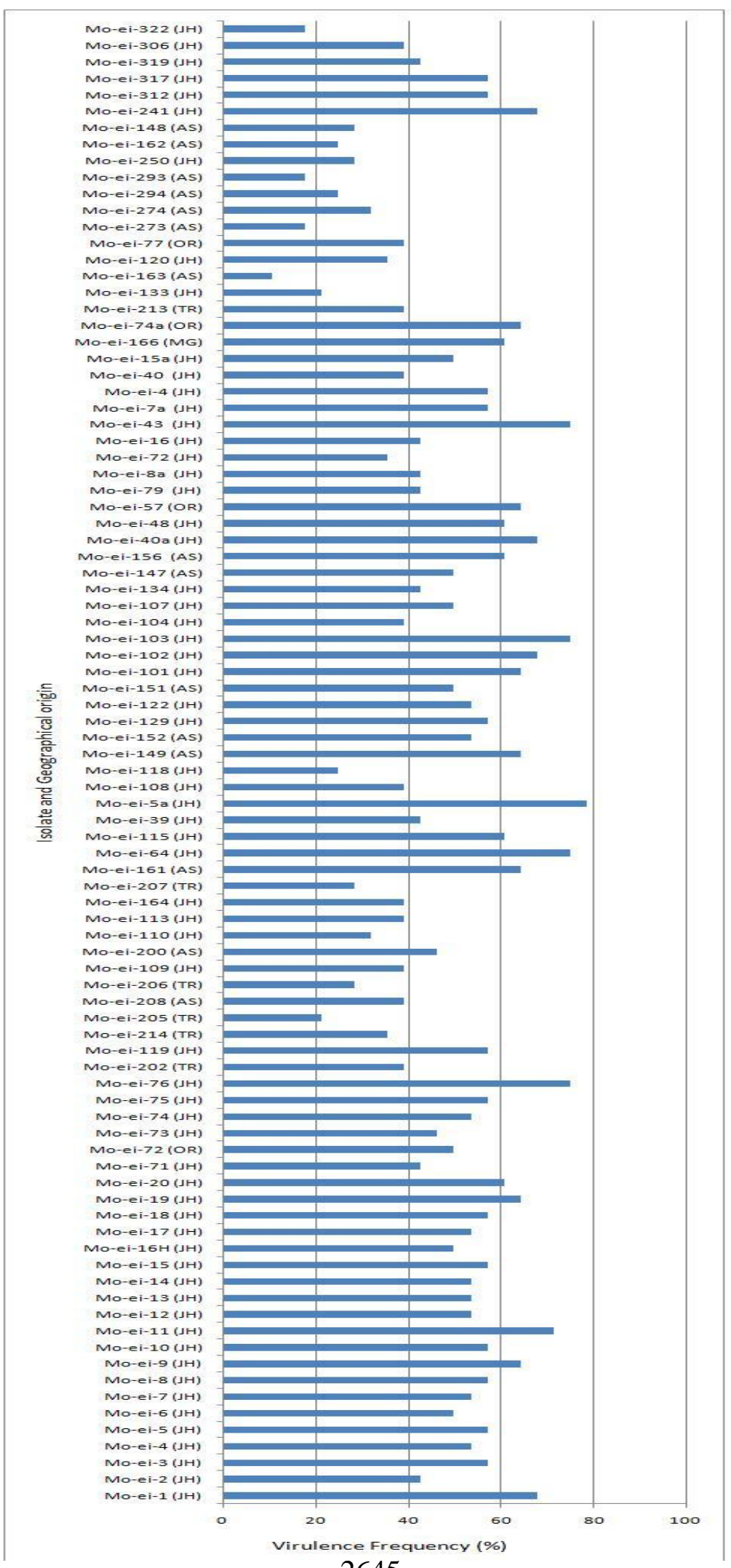


Table 3: Effective gene combinations for deployment in different Eastern and North Eastern states of India *IRBLTA2-RE

\begin{tabular}{|c|c|c|c|c|c|c|}
\hline \multirow[t]{2}{*}{ Sl.no. } & \multirow{2}{*}{$\begin{array}{c}\text { Gene } \\
\text { combinations }\end{array}$} & \multicolumn{5}{|c|}{ Percentage of pathogen population excluded } \\
\hline & & Jharkhand & Orissa & Assam & Meghalaya & Tripura \\
\hline 1 & $P i 9+P i t a 2 *$ & 100 & 100 & 100 & 100 & 100 \\
\hline 2 & $P i 9+P i z 5$ & 98.18 & 100 & 100 & 100 & 100 \\
\hline 3 & $P i 9+P i z$ & 96.36 & 100 & 93.3 & 100 & 100 \\
\hline 4 & $P i 9+P i l$ & 96.36 & 100 & 100 & 100 & 100 \\
\hline 5 & $P i z 5+P i 1$ & 96.36 & 100 & 87.5 & 100 & 80 \\
\hline 6 & $P i z+P i l$ & 90.9 & 100 & 75 & 100 & 100 \\
\hline
\end{tabular}

However, virulence to almost all the resistant genes was identified in pathogen population. None of the genes showed incompatible reaction to all the isolates except Tetep. Therefore, stacking of multiple R-genes in combination is an excellent strategy to achieve broad spectrum resistance. Results suggest that among the R-gene combinations identified, $P i-9+$ Pita $^{2}$ appear to have potential for effective management of rice blast disease across all locations by excluding all virulences of North-East and Eastern Indian pathogen. DNA markers closely linked to major blast resistance genes are available and their incorporation can now be accelerated using marker assisted selection. To our knowledge, this was the first report to describe the resistance spectra of 26 different blast resistant genes providing information about possible combination of genes which could be used to develop durable system of protection to this blast disease in this region.

\section{Acknowledgement}

The authors acknowledge the National Agriculture Innovative Project- Component 4, for financial support for this research. This work was conducted at the Central Rainfed Upland Rice Research Station, Hazaribag, Jharkhand, India.
Abbreviation: $M$. oryzae: Magnaporthe oryzae; LTH: Lijinanxintuanheigu; Avr: Avirulence; IRRI: International Rice Research Institute; SES: Standard evaluation system; R: Resistant; S: susceptible; R- gene: Resistant gene; AS: Assam; Jh: Jharkhand; MG: Meghalaya; OR: Odissa; TR: Tripura

\section{References}

Atkins, J.G., Robert, A.L., Adaair, C.R., Goto, K., Kozaka, T., Yanagida, R., Yamada, M. and Matsumoto, S. 1967. An international set of rice varieties for differentiating races of Pyricularia oryzae. Phytopathology 57:297-301.

Bohnert, H. U., Fudal, I., Dioh, W., Tharreau, D., Notteghem, J. L., and Lebrun, M. H., 2004. A putative polyketide synthase/peptide synthetase from Magnaporthe grisea signals pathogen attack to resistant rice. Plant Cell. 16, 2499-2513.

Bonman, J.M., 1992. Blast. In: Webster RK, Gunnell PS (eds) Compendium of rice diseases. APS Press, St. Paul, pp.1417.

Couch, B.C., Kohn, L.M., 2002. A multilocus gene genealogy concordant with host preference indicates segregation of a new species, Magnaporthe oryzae, 
from M. grisea. Mycologia. 94, 683693.

Dean, R.A., Talbot, N.J., Ebbole, D.J., Farman, M.L., Mitchell, T.K., Orbach, M.J., Thon, M., Kulkarni, R., Xu, J.R., Pan, H., Read, N. D., Lee, Y.H., Carbone, I., Brown, D., Oh, Y.Y., Donofrio, N., Jeong, J.S., Soanes, D.M., Djonovic, S., Kolomiets, E., Rehmeyer, C., Li, W., Harding, M., Kim, S., Lebrun, M.H., Bohnert, H., Coughlan, S., Butler, J., Calvo, S., Ma, L.J., Nicol, R., Purcell, S., Nusbaum, C., Galagan, J.E., and Birren, B. W. 2005. The genome of the rice blast fungus Magnaporthe grisea. Nature, 434, 980-986.

Fukuta, Y., Kobayashi, N., Noda, T., Hayashi, N., Cruz, C.M Vera., 2010. A research network for blast disease to build a stable rice production system. In Proc. 28 Inter. Rice Research Conf. 8-12 Nov 2010, OP09: Pest, Disease, and Weed Management. Vietnam.

Hayashi, N., Kobayashi, N., Vera, Cruz, C.M., Fukuta, Y., 2009. Protocol for the sampling of diseased specimens and evaluation of blast disease in rice. JIRCAS Working Rep. 63, 17-33.

http://ricecongress.com/previous/extPdfs/OP0 9-4058-Fukuta-fgh-edited2.pdf

Imam, J., Alam, S., Mandal, NP., Maiti, D., Variar, M., Shukla, P., 2015. Molecular Diversity and Mating Type Distribution of the Rice Blast Pathogen Magnaporthe oryzae in North-East and Eastern India. Indian journal of microbiology 55 (1), 108113

Inukai, T., Viet, D.L., Imbe, T., Ziegler, R.S., Kinoshita, T., Nelson, R.J., 1995. Identification of four resistant gene in Vietnames indica cultivar Tetep, Rice Genetics. News Letters. 12, 237-238.

Khush, S.G., Jena, K.K., 2009. Current status and future prospects for research on blast resistance in rice (Oryza sativa L.). Advances in Genetics, Genomics and Control of Rice Blast Disease. http://link.springer.com/chapter/10.10 07\%2F978-1-4020-9500-9_1.

Kim, Y.S., Oh, J.Y., Hwang, B.K., Kim, K.D., 2008. Variation in sensitivity of Magnaporthe oryzae isolates from Korea to edifenphos and iprobenfos. Crop Prot. 27, 1464-1470.

Kiyosawa, S. (1984) Establishment of differential varieties for pathogenicity test of rice blast fungus. Rice genet. Newsl., 1: 95-97. http://www. Gramene.org/newsletters/rice_genetics /rgn1/ v1I4.html.

Kiyosawa, S., 1982. Genetics and epidemiological modeling of breakdown of plant disease resistance. Annu. Rev. Phytopathol. 20, 93-117.

Kobayashi, N., Telebanco Yanoria, M.J., Tsunematsu, H., Kato, H., Imbe, T., Fukuta, Y., 2007. Development of new sets of international standard differential varieties for blast resistance in rice (Oryza sativa L.). JIRCAS Work Rep. 41(1), 31-37.

Lee, F.N., 1994. Rice breeding programs, blast epidemics and blast management in the United States. In: Zeigler, R.S., Leong, S.A., Teng, P.S. (Eds.), Rice Blast Disease. Oxon, CAB International, UK, pp. 489-500.

Lei, C., Hao, K., Yang, Y., Ma, J., Wang, S., Wang, J., Cheng, Z., Zhao, S., Zhang, X., Guo, X., Wang, C., Wan, J., 2013. Identification and fine mapping of two blast resistance genes in rice cultivar. The crop J. 1(1): 2-14.

Leung, H., Borromeom, E.S., Bernardoa, M.A., Notteghem, J. L., 1988. Genetic analysis of virulence in the rice blast fungus Magnaporthe grisea. Genetics. 78 (9), 1227-1233.

Li, W., Wang, B., Wu, J., Lu, G., Hu, Y., Zhang, X., Zhang, Z., Zhao, Q., Feng, 
Q., Zhang, H., Wang, Z., Wang, G.L., Han, B., Wang, Z., Zhou, B., 2009. The Magnaporthe oryzae avirulence gene AvrPiz-t encodes a predicted secreted protein that triggers the immunity in rice mediated by the blast resistance gene Piz-t. Mol. Plant Microbe. Interact. 22(4), 411-420.

Ling, K.C., Ou, S.H., 1969. Standardization of the international race numbers of Pyricularia oryzae. Phytopathology $59,339 \mathrm{e} 342$.

Ou, S.H., 1985. Rice Diseases, second ed. Kew, England.

RoyChowdhury, M., Jia, Y., Jackson, A., Jia, M.H, Fjellstrom, R., Cartwright, R.D., 2012. Analysis of rice blast resistance gene $P i-z$ in rice germplasm using pathogenictiy assays and DNA markers. Euphytica. 184, 35-46.

Saad, A., Habinuddin, H., 2010. Pathotypes and virulence of Xanthomonas oryzae causing bacterial blight disease of rice in Peninsular Malaysia. J. Trop. Agric. and Fd. Sc. 38(2), 257- 266

Tsunematsu, H., Yanoria, M.J.T., Ebron, L.A., Hayashi, N., Ando, I., Kato, H., Imbe, T., Khush, G.S., 2000. Development of monogenic lines of rice for rice blast resistance. Breed. Sci. 50, 229-234.

Valent, B., Farrall, L., Chumley, F.G., 1991. Magnaporthe grisea genes for pathogenicity and virulence through a series of backcrosses. Genetics. 127, 87-101.

Variar, M., Vera Cruz, C.M., Carrillo, M.G., Bhatt, J.C., Sangar, R.B.S., 2009. Rice blast in India and strategies to develop durably resistant cultivars. In: Liang, Wang, G., Valent, B. (Eds.), Advances in Genetics, Genomics and Control of Rice Blast Disease. Springer Publication, pp. 359-374.

Widawsky, D.A., O'Toole, J.C., 1990. Prioritizing the rice biotechnology research agenda for Eastern India. Rockefeller Foundation, New York, $86 \mathrm{pp}$.

Yamada, M., 1985. Pathogenic specialization of rice blast fungus in Japan. Japan Agricultural Research Quarterly, Tokyo, v. 19, p. 178-183

Zhou, E., Jia, Y., Singh, P., Correll, J.C., Lee, F.N., 2007. Instability of the Magnaporthe oryzae avirulence gene AVR-Pita alters virulence. Fung. Genet. Biol. 44 (10), 1024-1034.

\section{How to cite this article:}

Shamshad Alam, Jahangir Imam, Dipankar Maiti, N.P. Mandal, Chandeshwar Prasadand Mukund Variar. 2019. Identification of Broad Spectrum Blast Resistance Genes for North-East and Eastern India using Standard International Blast Differential. Int.J.Curr.Microbiol.App.Sci. 8(04): 2639-2648. doi: https://doi.org/10.20546/ijcmas.2019.804.308 